\title{
PENERAPAN MODEL PEMBELAJARAN KONSTRUKTIVIS UNTUK MENINGKATKAN HASIL BELAJAR PKn SISWA KELAS V SD NEGERI 1 SAWANGOAHA
}

\author{
Hirawati $^{1)}$, Lisnawati Rusmin ${ }^{2)}$ \\ 1) SDN 1 Sawangoaha, Kolaka, Indonesia \\ ${ }^{2)}$ Jurusan PGSD, Universitas Halu Oleo, Kendari, Indonesia \\ email: hirawatii.pji@gmail.com
}

\begin{abstract}
Abstrak: Tujuan dari penelitian ini adalah untuk meningkatkan hasil belajar PKn siswa pada materi Peraturan Perundang-Undangan melalui penerapan model pembelajaran konstruktivis di kelas V SD Negeri 1 Sawangoaha Kabupaten Kolaka Utara. Prosedur penelitian yaitu; (a) perencanaan (planning), (b) pelaksanaan tindakan (action), (c) observasi dan evaluasi (observation and evaluation), dan (d) refleksi (reflection). Jenis data yaitu data kualitatif dan data kuantitatif. Data kualitatif diperoleh melalui lembar observasi sedangkan data kualitatif melalui tes hasil belajar. Hasil analisis penelitian pada siklus I jumlah siswa yang tuntas mencapai 19 siswa $(73,08 \%)$ dan siswa yang tidak tuntas mencapai 7 siswa $(26,92 \%)$ dengan nilai rata-rata 70,96 sedangkan pada siklus II jumlah siswa yang tuntas mencapai 24 siswa $(92,31 \%)$ dan siswa yang tidak tuntas mencapai 2 siswa $(7,69 \%)$ dengan nilai rata-rata 80 . Aktivitas belajar siswa pada siklus I pertemuan pertama mencapai $70,59 \%$ dan pertemuan kedua mencapai $82,35 \%$ sedangkan pada siklus II pertemuan pertama mencapai $88,24 \%$ dan pertemuan kedua mencapai $100 \%$. Aktivitas mengajar guru siklus I pertemuan pertama mencapai $70,59 \%$ dan pertemuan kedua mencapai $82,35 \%$ sedangkan pada siklus II pertemuan pertama mencapai $88,24 \%$ dan pertemuan kedua mencapai $100 \%$.
\end{abstract}

Kata kunci: Model pembelajaran, konstruktivis, hasil belajar

\section{THE APPLICATION OF CONSTRUCTIVIC LEARNING MODELS TO IMPROVE CLASS V STUDENT LEARNING RESULTS OF SD NEGERI 1 SAWANGOAHA}

\begin{abstract}
The aim of the study was to improve student learning outcomes on the Laws and Regulations material through the implementation of the constructivist learning model in class V SD Negeri 1 Sawangoaha, North Kolaka Regency. Research procedures, namely; (a) planning (planning), (b) implementation of action (action), (c) observation and evaluation (observation and evaluation), and (d) reflection. Types of data are qualitative data and quantitative data. Qualitative data were obtained through observation sheets, while qualitative data were obtained through learning outcomes tests. The results of the research analysis in the first cycle, the total number of students who completed reached 19 students (73.08\%) and 7 students who did not complete the study (26.92\%) with an average score of 70.96 while in the second cycle the number of students who completed reached 24 students (92.31\%) and students who did not complete reached 2 students (7.69\%) with an average score of 80. Student learning activities in the first cycle of the first meeting reached $70.59 \%$ and the second meeting reached $82.35 \%$ whereas in the second cycle the first meeting reached $88.24 \%$ and the second meeting reached 100\%. The teaching activity of the teacher in the first cycle of the first meeting reached $70.59 \%$ and the second meeting reached $82.35 \%$, while in the second cycle the first meeting reached $88.24 \%$ and the second meeting reached $100 \%$.
\end{abstract}

Keywords: Constructivist learning model; learning outcomes

\section{Pendahuluan}


Seiring dengan perkembangan zaman, pendidikan merupakan investasi penting yang menentukan masa depan bangsa. Dewasa ini, pesatnya perkembangan teknologi dan informasi memiliki peranan yang sangat penting dalam dunia pendidikan di era globalisasi dan pasar bebas dunia. Sumber Daya Manusia (SDM) yang berkualitas sangat diperlukan bagi negaranegara maju dan berkembang termasuk Indonesia disaat persaingan semakin tajam. Peningkatan kualitas SDM sangat tergantung pada kualitas pendidikan di suatu negara.

Siswa sebagai generasi penerus bangsa diharapkan dapat meningkatkan kualitas untuk kemajuan negara melalui pendidikan di sekolah. Tujuan pendidikan adalah untuk membantu berkembangnya peserta didik agar menjadi manusia yang beriman dan bertaqwa kepada Tuhan Yang Maha Esa, berakhlak mulia, sehat, berilmu, cakap, kreatif, mandiri dan menjadi warga negara yang demokratis dan bertanggung jawab. Dunia pendidikan mencetak siswa-siswa berkualitas yang diharapkan dapat berpikir secara kritis, kreatif, inovatif dan berwawasan luas untuk bersaing meningkatkan mutu pendidikan dan prestasi belajarnya (Syah, 2010, p.12).

Sistem pembelajaran yang baik tidak hanya membekali siswa dengan ilmu, tetapi juga mampu menjadikan siswa lebih mandiri, selalu bersikap positif untuk mengembangkan segala kelebihan yang dimilikinya sesuai dengan bakat dan minatnya serta mampu menghadapi lingkungan dan perkembangan zaman, sehingga pada akhirnya siswa dapat mensukseskan pembangunan di segala bidang dan aspek kehidupan masyarakat, bangsa dan negara. Tujuan pendidikan adalah untuk membentuk siswa mempunyai kepercayaan diri yang cukup untuk dapat mengembangkan kemampuan yang dimilikinya.

Secara umum pendidikan Indonesia masa kini sudah lebih maju bila dibandingkan dengan kondisi pendidikan bangsa sepuluh tahun yang lalu. Berbagai prestasi internasional telah diraih oleh siswa dari berbagai tingkatan pendidikan di Indonesia, mulai dari pendidikan tinggi, menengah dan dasar. Prestasi yang diraih tersebut menggambarkan bahwa pendidikan Indonesia tidak kalah dari pendidikan di Negara lain.

Namun demikian, dari hasil observasi awal hasil belajar siswa di tingkat Sekolah Dasar khususnya SD Negeri 1 Sawangaoha Kabupaten Kolaka Utara masih rendah khususnya mata pelajaran PKn materi Peraturan Perundang-Undangan. Selama dua tahun terakhir, nilai materi Peraturan Perundang-Undangan siswa Kelas V SD Negeri 1 Sawangaoha pada mata pelajaran PKn masih di bawah KKM yang ditetapkan sekolah yakni minimal siswa memperoleh nilai 70. Ketuntasan hasil belajar siswa materi Peraturan Perundang-Undangan pada semester ganjil tahun pelajaran 2015/2016 adalah 68\% dengan nilai rata-rata adalah 62 .

Rendahnya hasil belajar siswa disebabkan oleh beberapa faktor diantaranya adalah proses pembelajaran yaitu model pembelajaran yang diterapkan oleh guru yang tidak tepat. Dalam pembelajaran diperlukan kesesuaian antara pengalaman guru dengan siswa. Kebermaknaan pembelajaran PKn sangat ditentukan oleh kegiatan-kegiatan nyata, karena siswa Sekolah Dasar belum dapat menghubungkan alasan yang bersifat hipotesis. Pengetahuan tumbuh berkembang melalui pengalaman dan pemahaman akan berkembang semakin dalam dan semakin kuat apabila selalu diuji dengan pengalaman baru. Menurut Ulfah (2016, p.1610) hasil belajar merupakan hasil keberhasilan dari interaksi belajar mengajar yang mencakup bidang kognitif, afektif, dan psikomotorik yang ditunjukkan dengan perubahan tingkah laku yang khas. Menurut Mulyana dan Nana dalam Patimasang (2014, p.135) belajar merupakan perubahan perilaku sebagai fungsi pengalaman, yang mencakup perubahan-perubahan afektif, psikomotorik, dan kognitif, yang tidak dihasilkan oleh sebab-sebab lain. Pengorganisasian proses belajar mengajar dikelas dengan strategi pembelajaran yang tepat adalah salah satu hal yang harus benar-benar dipahami oleh guru selaku pendidik untuk meningkatkan aktivitas sekaligus hasil belajar siswa (Untari, 2013, p.79) 
Dalam hubungannya dengan uraian di atas, pembelajaran PKn pada umumnya masih dominan menggunakan metode ceramah dan penugasan yang terkesan kaku sehingga kurang memberikan kesempatan kepada siswa untuk berinteraksi dengan benda-benda konkrit. Selama ini, siswa kurang diberi kesempatan untuk melakukan observasi, penyelidikan, memahami sendiri, dan melakukan eksperimen terhadap konsep-konsep PKn melalui pengalaman nyata. Sementara dari kajian awal terhadap guru dan siswa di SD terungkap, guru kesulitan membelajarkan siswa dalam pelajaran PKn pada umumnya. Sehubungan dengan hal tersebut di atas, karena siswa adalah penerima, guru sebagai pengelola pembelajaran di kelas perlu memperhatikan apa yang menjadi kebutuhan siswa. Hal ini perlu dilakukan agar para siswa memperoleh kepuasan belajar dengan penuh gairah yang dapat membangkitkan antusias serta motivasi siswa dalam menuangkan semua ide yang terkait dengan mata pelajaran yang diberikan, khususnya mata pelajaran PKn. Dengan demikian kegiatan pembelajaran yang dilaksanakan akan memunculkan kreativitas tinggi yang pada akhirnya dapat meningkatkan hasil belajar siswa.

Adapun pengemasan pembelajaran yang disarankan adalah pembelajaran konstruktivis. Pembelajaran kontruktivis merupakan pembelajaran yang menuntut siswa untuk menemukan ide, opini dan aktif dalam pembelajaran. Siswa bukan hanya memperoleh materi-materi atau ide yang disampaikan oleh guru tetapi berusaha untuk mendapatkan ide berdasarkan materi yang dijelaskan guru.

Atas dasar pertimbangan yang mengarah pada peningkatan hasil belajar siswa, maka penulis melakukan penelitian tindakan kelas dengan judul "Penerapan Model Pembelajaran Konstruktivis pada Mata Pelajaran PKn Materi Peraturan Perundang-Undangan untuk Meningkatkan Hasil Belajar Siswa Kelas V SD Negeri 1 Sawangaoha Kabupaten Kolaka Utara".

Hasil penelitian yang dilakukan oleh Nurdiana (2011) dengan judul "Penerapan Model Pembelajaran Kontruktivis dalam Meningkatkan Hasil Belajar PKn Siswa pada Materi Globalisasi di Kelas IV SDN 03 Baruga Kota Kendari”. Hasil belajar juga mengalami peningkatan dari $60 \%$ pada siklus I menjadi $80 \%$ pada siklus II. Hasil penelitian yang dilakukan oleh Uliana (2011) dengan judul "Penerapan Model Pembelajaran Kontruktivis dalam Meningkatkan Hasil Belajar PKn Siswa Kelas IV SDN 14 Sawerigadi Kecamatan Barangka Kabupaten Kolaka Utara". Pada siklus I ketuntasan hasil belajar siswa mencapai 55,26\% (21 dari 38 siswa) meningkat menjadi 100\% (38 siswa) pada siklus II.

Model Pembelajaran Kontruktivis dirancang secara matang dan dilaksanakan secara tepat diharapkan dapat mendorong siswa lebih dapat meningkatkan persiapan dalam menerima pelajaran. Peningkatan motivasi belajar siswa juga diharapkan membawa dampak positif yaitu peningkatan hasil belajar siswa. Menurut Chujaemah dalam Priartini, dkk (2017, p.28) langkah - langkah penerapan model konstruktivisme: (1) fase start, (2) fase eksplorasi, (3) fase refleksi, dan (4) fase aplikasi dan diskusi. Senada dengan Suherman dalam Kasmina (2012, p.62) Pengetahuan dikembangkan secara aktif oleh siswa sendiri dan tidak diterima secara pasif dari sekitarnya. Model pembelajaran konstruktivis menekankan bahwa belajar adalah kegiatan yang aktif, dimana pelajar membangun sendiri pengetahuannya dan bertanggungjawab atas hasil belajarnya. Melalui model pembelajaran konstruktivisme, siswa diharapkan mampu mengkonstruksikan pengetahuan mereka sendiri, dan tidak mengharuskan siswa menghapal faktafakta. Sesuatu yang baru ditemukan oleh siswa, bukan dari apa kata guru (Sujarwanto, 2016, p.71).

Masalah dalam penelitian adalah apakah penerapan model pembelajaran konstruktivis pada materi Peraturan Perundang-Undangan dapat meningkatkan hasil belajar siswa kelas V SD Negeri 1 Sawangoaha Kabupaten Kolaka Utara? Tujuan penelitian adalah untuk meningkatkan hasil belajar PKn siswa pada materi Peraturan Perundang-Undangan 
melalui penerapan model pembelajaran konstruktivis di kelas V SD Negeri 1 Sawangoaha Kabupaten Kolaka Utara. Penelitian ini diharapkan dapat memberikan manfaat bagi guru, siswa, sekolah dan penelitian lainnya.

\section{Metode}

Jenis penelitian ini adalah penelitian tindakan kelas (PTK). Penelitian ini adalah suatu bentuk kajian yang bersifat reflektif oleh pelaku tindakan. Dalam prosedur pelaksanaannya dilakukan dengan proses pengkajian berdaur yang terdiri dari empat tahap yaitu: merencanakan, melakukan tindakan, mengamati, evaluasi dan refleksi (Kurniasih dan Sani, 2014:3). Penelitian ini dilaksanakan semester ganjil tahun pelajaran 2016/2017 di Kelas V SD Negeri 1 Sawangaoha Kabupaten Kolaka Utara. Subjek dalam penelitian ini adalah guru dan siswa kelas V SD Negeri 1 Sawangaoha. Jumlah siswa sebanyak 26 orang terdiri dari 12 orang laki-laki dan 14 orang perempuan. Faktor yang diteliti dalam penelitian ini adalah 1) faktor siswa, 2) Faktor guru dan faktor 3) hasil belajar. Penelitian Tindakan Kelas ini dilaksanakan dalam 2 (dua) siklus. Adapun prosedur penelitian tindakan ini meliputi: (1) Perencanaan, (2) Pelaksanaan Tindakan, (3) Observasi dan Evaluasi, dan (4) Refleksi dalam setiap siklus. Jenis data yaitu data kualitatif dan data kuantitatif. Data kualitatif diperoleh melalui observasi, menggunakan lembar observasi sedangkan data kuantitatif diperoleh melalui tes setiap akhir siklus Tindakan.

Analisis data dalam penelitian ini adalah menggunakan statistik deskriptif untuk menghitung nilai siswa, rata-rata nilai siswa, dan ketuntasan belajar.

Indikator kinerja dalam penelitian adalah keberhasilan proses pembelajaran dan hasil belajar siswa. Proses pembelajaran dikatakan berhasil jika minimal $80 \%$ komponen skenario pembelajaran terlaksana dengan baik. Hasil belajar siswa dikatakan mencapai indikator keberhasilan jika minimal $80 \%$ siswa telah memperoleh nilai $\geq 70$, sesuai kriteria ketuntasan minimal (KKM) yang ditetapkan di sekolah.

\section{Hasil}

Hasil Belajar Siswa

Hasil analisis penelitian pada siklus I jumlah siswa yang tuntas mencapai 19 siswa $(73,08 \%)$ dan siswa yang tidak tuntas mencapai 7 siswa $(26,92 \%)$ dengan nilai rata-rata 70,96 sedangkan pada siklus II jumlah siswa yang tuntas mencapai 24 siswa $(92,31 \%)$ dan siswa yang tidak tuntas mencapai 2 siswa $(7,69 \%)$ dengan nilai rata-rata 80. Perbandingan ketuntasan belajar siswa siklus II dan tes akhir siklus I dapat ditampilkan pada Grafik 1. berikut.

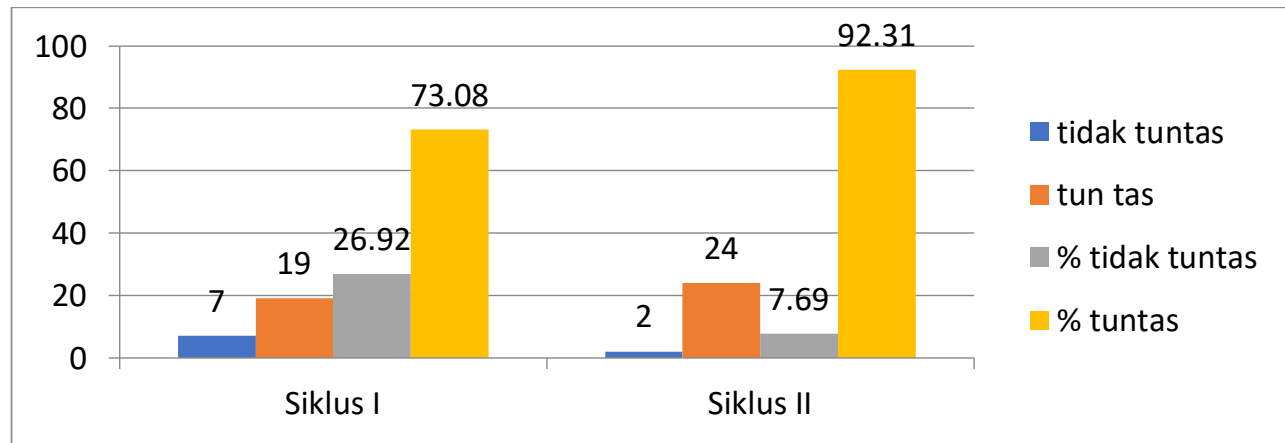

Gambar 1.Grafik Ketuntasan Hasil Belajar Siswa Siklus I dan Siklus II 
Aktivitas Mengajar Guru

Aktivitas mengajar guru siklus I pertemuan pertama mencapai $70,59 \%$ dan pertemuan kedua mencapai $82,35 \%$ sedangkan pada siklus II pertemuan pertama mencapai $88,24 \%$ dan pertemuan kedua mencapai $100 \%$.

Aktivitas Belajar Siswa

Aktivitas belajar siswa pada siklus I pertemuan pertama mencapai $70,59 \%$ dan pertemuan kedua mencapai $82,35 \%$ sedangkan pada siklus II pertemuan pertama mencapai $88,24 \%$ dan pertemuan kedua mencapai $100 \%$.

\section{Pembahasan}

\section{Hasil Belajar Siswa}

Hasil belajar adalah kemampuan siswa dalam menguasai bahan-bahan yang telah diajarkan kepadanya. Hasil belajar merupakan kemampuan yang diperoleh anak sebagai bukti usaha setelah melalui kegiatan pembelajaran (Abdurrahman, 2003, p.37). Sebagai bukti usaha selama proses pembelajaran, hasil belajar siswa diperoleh setelah tindakan pembelajaran akhir siklus melalui evaluasi dengan menggunakan tes hasil belajar. Hasil evaluasi siklus I menunjukkan bahwa siswa yang memperoleh skor antara 0-69 berjumlah 7 orang $(26,92 \%)$, siswa yang memperoleh skor rentang 70-100 berjumlah 19 orang $(73,08 \%)$. Ketuntasan belajar siswa pada tindakan pembelajaran siklus I mencapai 73,08 \% dan siswa yang belum mencapai ketuntasan belajar adalah 26,92 \%. Setelah pelaksanaan tindakan siklus II, diadakan evaluasi dengan tes. Hasil evaluasi tindakan siklus II menunjukkan peningkatan dibanding evaluasi tindakan siklus I, dimana pada evaluasi siklus II siswa yang memperoleh skor $\geq 70$ berjumlah 24 orang $(92,31 \%)$ dan siswa yang memperoleh skor $<70$ berjumlah 1 orang $(7,69 \%)$ dan secara rata-rata juga meningkat menjadi 80 . Hasil tersebut sudah jauh meningkat dibanding hasil belajar siswa pada siklus I.

Grafik 1 menunjukkan bahwa hasil belajar siswa pada pembelajaran siklus II sudah lebih baik daripada Siklus I. Hasil evaluasi pada siklus II menunjukkan bahwa ketuntasan belajar siswa adalah $92,31 \%$. Hal ini berarti telah mencapai indikator yang telah ditetapkan, sedangkan hasil observasi terhadap pelaksanaan pembelajaran bisa dikatakan sempurna, yakni seluruh komponen dalam RPP telah dilaksanakan dengan baik sesuai yang diharapkan. Karena kedua indikator telah tercapai, ini berarti hipotesis tindakan penelitian telah tercapai yaitu hasil belajar PKn siswa Kelas V SD Negeri 1 Sawangoaha pada materi Peraturan Perundang-Undangan dapat ditingkatkan melalui penerapan model pembelajaran konstruktivis.

Aktivitas Mengajar Guru

Pada pembelajaran siklus I observasi yang dilakukan guru menggambarkan bahwa kemampuan guru mengelola pembelajaran masih rendah. Persentase keberhasilan aktivitas mengajar guru siklus I pertemuan pertama adalah 70,59\% dan pertemuan kedua adalah $82,35 \%$ dengan rata-rata $76,47 \%$. Aspek-aspek yang belum terlaksana dengan baik adalah penjelasan materi pembelajaran dengan menggunakan gambar dan proses pelaksanaan diskusi.

Rendahnya tingkat keterlaksanaan RPP berpengaruh langsung pada aktivitas belajar siswa. Aktivitas siswa pada pembelajaran siklus I masih rendah dimana faktor utama kemampuan siswa belum maksimal yakni kemampuan bertanya dan mengemukakan pendapat. Untuk meningkatkan persentase keberhasilan aktivitas guru dan siswa, sebelum melaksanakan tindakan siklus II, peneliti dan guru kolaborator melakukan diskusi untuk mengatasi kelemahan pada tindakan siklus I. Dari hasil diskusi tersebut, diperoleh kesimpulan bahwa faktor utama yang dilakukan guru adalah menumbuhkan kepercayaan diri siswa untuk 
berani bertanya dan mengemukakan pendapat. Upaya yang dilakukan guru tidak sia-sia karena pada tindakan siklus II aktivitas guru.

Aktivitas Belajar Siswa

Keberhasilan aktivitas mengajar guru berdampak pada peningkatan keberhasilan aktivitas belajar siswa. Persentase keberhasilan aktivitas belajar siswa siklus I pertemuan pertama adalah $70,59 \%$ dan pertemuan kedua adalah $82,35 \%$ dengan rata-rata $76,47 \%$. Persentase keberhasilan aktivitas belajar siswa pada siklus II pertemuan pertama adalah $88,24 \%$ dan pertemuan kedua adalah $100 \%$ dengan rata-rata persentase keberhasilan adalah $94,12 \%$. Hasil tersebut telah masuk pada kategori sangat baik berdasarkan indikator keberhasilan pelaksanaan penelitian. Dari hasil diskusi tersebut, diperoleh kesimpulan bahwa faktor utama yang dilakukan guru adalah menumbuhkan kepercayaan diri siswa untuk berani bertanya dan mengemukakan pendapat. Upaya yang dilakukan guru tidak sia-sia karena pada tindakan siklus II aktivitas belajar siswa meningkat.

Berdasarkan hasil observasi pada siklus I, guru dan siswa telah melakukan kegiatan pembelajaran Pendidikan Kewarganegaraan materi Peraturan Perundang-Undangan dengan menerapkan model pembelajaran konstruktivis, namun masih terdapat kekurangan. Diantaranya ada sebagian siswa yang yang belum mampu memahami pesan-pesan dari gambar yang berkaitan dengan materi Peraturan Perundang-Undangan, kekurangan yang berasal dari guru adalah belum terlaksananya semua komponen dalam RPP. Hal itu dikarenakan guru belum dapat mengatur waktu sebaik mungkin. Melihat kekurangan yang masih ada serta hasil Pendidikan Kewarganegaraan materi Peraturan Perundang-Undangan siswa pada tindakan siklus I belum memenuhi indikator keberhasilan yang telah ditetapkan, maka penelitian dilanjutkan pada tindakan siklus II. Hal-hal yang harus diperbaiki pada tindakan siklus II adalah guru harus mendorong siswa agar mampu memahami pesan dari gambar yang berkaitan dengan Peraturan Perundang-Undangan. Guru juga harus mampu mengelola waktu dengan efisien agar semua tahapan kegiatan dalam RPP dapat terlaksana.

Konstruktivis merupakan salah satu strategi yang meningkatkan kemampuan bernalar siswa untuk memahami konsep-konsep pembelajaran. Hal ini disebabkan prinsipprinsip pembelajaran konstruktivis dapat menjembatani konsep-konsep PKn yang masih kabur melalui kegiatan pengamatan sehingga pengetahun yang baru dapat menyatu dengan pengetahuan yang telah dimiliki siswa. Hal itu sejalan dengan pendapat Bruner yang menyatakan bahwa pembelajaran konstruktivis dimulai dari isu-isu yang berada di sekeliling siswa, keaktifan dan keterlibatan siswa dalam proses pembelajaran sesuai dengan kemampuan, pengetahuan awal dan cara belajar siswa. Guru bertindak sebagai fasilitator yang harus memahami mental dan sikap siswa sehingga dapat membantu siswa memecahkan permasalahan dalam proses pembelajaran. Dalam proses pembelajaran, guru mengarahkan pemikiran siswa pada materi pelajaran. Pemahaman siswa terhadap materi pelajaran diperoleh melalui pengamatan, diskusi dan kerja sama dengan siswa lain. Pada pembelajaran PKn materi Peraturan Perundang-Undangan, guru memberikan gambar yang berhubungan dengan materi Peraturan Perundang-Undangan kemudian mengarahkan siswa untuk mengamati dan menemukan masalah berkaitan dengan materi pelajaran. Masalah yang ditemukan siswa, didiskusikan secara bersama dalam kelompok atau kelas. Menururt Hamalik dalam (Nupiksani. 2015, p.15) bahwa hasil belajar menunjukkan kepada prestasi belajar, sedangkan prestasi belajar itu merupakan indikator adanya derajat perubahan tingkah laku siswa. 


\section{Simpulan}

1. Aktivitas mengajar guru Kelas V SD Negeri 1 Sawangoaha pada materi Peraturan Perundang-Undangan dapat ditingkatkan melalui penerapan model pembelajaran konstruktivis. Hal ini dapat dilihat dari persentase keberhasilan aktivitas mengajar guru, pada siklus I pertemuan pertama $70,59 \%$ dan pertemuan kedua $82,35 \%$ meningkat menjadi $88,24 \%$ pertemuan pertama dan $100 \%$ pertemuan kedua untuk siklus II.

2. Aktivitas belajar PKn siswa Kelas V SD Negeri 1 Sawangoaha pada materi Peraturan Perundang-Undangan dapat ditingkatkan melalui penerapan model pembelajaran konstruktivis. Hal ini dapat dilihat dari persentase keberhasilan aktivitas belajar siswa, pada siklus I pertemuan pertama $70,59 \%$ dan pertemuan kedua $82,35 \%$ meningkat menjadi $88,24 \%$ pertemuan pertama dan $100 \%$ pertemuan kedua untuk siklus II.

3. Hasil belajar PKn siswa Kelas V SD Negeri 1 Sawangoaha pada materi Peraturan Perundang-Undangan dapat ditingkatkan melalui penerapan model pembelajaran konstruktivis. Hal ini dapat dilihat dari peningkatan hasil belajar siswa Kelas V SD Negeri 1 Sawangoaha. Pada siklus I siswa yang tuntas sebanyak 19 siswa atau 73,08 \% sedangkan yang tidak tuntas sebanyak 7 siswa atau 26,92 \% dengan nilai rata-rata 70,96 dan pada siklus II siswa yang tuntas sebanyak 24 siswa atau 92,31\% sedangkan yang tidak tuntas sebanyak 2 siswa atau 7,69\% dengan nilai rata-rata 80.

\section{Referensi}

Abdurrahman, H. (2003). Pengelolaan Pengajaran. Ujung Pandang: IAIN Alauddin.

Kasmina. (2012). Penerapan Pendekatan Konstruktivisme Pada Pembelajaran IPA Untuk Meningkatkan Hasil Belajar Siswa di Kelas III SD Integral Rahmatullah Tolitoli. Jurnal Kreatif Tadulako Online Vol. 4 No. 9. 60-73. https://media.neliti.com/media/publications/118422-ID-penerapan-pendekatankonstruktivisme-pad.pdf

Kurniasih I. dan Sani B. (2014). Teknik dan Cara Mudah Membuat Penelitian Tindakan Kelas untuk Pengembangan Profesi Guru. Yogakarta: Kata Pena.

Nupiksani, Sri. (2015). Meningkatkan Hasil Belajar IPS Melalui Penerapan Model Pembelajaran Group Investigation Pada Siswa Kelas VI SDN Rejoagung 01 Kecamatan Semboro Kabupaten Jember. Pancaran, Vol. 4, No. 4, hal 13-24. https://jurnal.unej.ac.id/index.php/pancaran/article/download/2174/1768/

Patimasang, (2014). Peningkatan Hasil belajar IPS dengan menggunakan Metode Kerja Kelompok pada Siswa Kelas IV SDN Silampayang. Jurnal Kreatif Tadulako Online Vol.2 No. 4. 132-150. https://media.neliti.com/media/publications/118659-IDpeningkatan-hasil-belajar-ips-dengan-men.pdf

Priartini, Dera Agustina, Ani Hendriani, \& Fitriani, Andhin Dyas. (2017). Penerapan Model Konstruktivisme Untuk Meningkatkan Pemahaman Konsep Bangun Ruang Peserta Didik SD. Jurnal Pendidikan Guru Sekolah Dasar, Vol. I1 No. 1I, Juni 2017, hlm. 2635. https://ejournal.upi.edu/index.php/jpgsd/article/download/13257/7771 
Sujarwanto, S. (2016). Penerapan Model Pembelajaran Konstruktivisme Pada Materi CiriCiri Mahluk Hidup Di Kelas III A SD Negeri Keputran. Mimbar Sekolah Dasar, 3(1), 69-80. doi:http://dx.doi.org/10.17509/mimbar-sd.v3i1.2357.

Suparno. (2008). Teori Perkembangan Kognitif Jean Piaget. Kanisius: Yogyakarta.

Syah, Muhibin. (2010). Psikologi Pendidikan dengan Pendekatan Baru. Bandung: Remaja Rosdakarya

Ulfah, KR, Anang Santoso, \& Utaya, Sugeng. (2016). Hubungan Motivasi Dengan Hasil Belajar IPS. Jurnal Pendidikan: Teori, Penelitian, dan Pengembangan Volume: 1 Nomor: 8. 1607-1611.

http://journal.um.ac.id/index.php/jptpp/article/view/6678/2885

Untari, Yusrina Anggraini. (2013). Peningkatan Hasil Belajar IPS Siswa Kelas V Melalui Metode Simulasi Improved Results of IPS Learning Student Class V through Simulation Method. Psikopedagogia Jumal Bimbingan dan Konseling. Vol. 2, No. 2. 78-84. http://journal.uad.ac.id/index.php/PSIKOPEDAGOGIA/article/view/2574/2792

Usman dan Setiawati. (1993). Upaya Optimalisasi Kegiatan Belajar Mengajar. Jakarta: PT. Remaja Rosdakarya. 